\title{
IDENTIFIKASI SIRIP IKAN HIU YANG DIDAPAT DARI PENGUMPUL DI MINAHASA TENGGARA MENGGUNAKAN DNA BARCODE
}

\author{
(Identification of Shark Fins Collected from Fins Collector in Southeast Minahasa \\ Using DNA Barcode)
}

\section{Andre Wehantouw ${ }^{{ }^{*}}$, Elvy Like Ginting ${ }^{1}$, Stenly Wullur ${ }^{1}$}

1. Program Studi IImu Kelautan, Fakultas Perikanan dan IImu Kelautan, Universitas Sam Ratulangi, Manado.

*e-mail : andre.wehantouw@yahoo.co.id

Global shark populations decline significantly due to massive and uncontrol capture, slow reproductive and low fecundity rate of the species. Indonesia is one of the biggest contributors to the world's shark fin trade. The high trade activities have significant effect on shark populations and are the source of declining quality of marine ecosystem. Objective of the present study was to identify shark fins collected from fins collectors in Tumbak, Southeast Minahasa using DNA barcodes. Genomic DNA Extraction of dried fins was conducted following procedure DNeasy Blood \& Tissue kit, Cytochrome Oxidase Subunit 1 (COI) gene amplification was performed using primer Fish BCL5 (TCAACYAATCAYAAAGATATYGGCAC) and HCO2198 (TAAACTTCAGGGTGACCAAAAAA TCA). Sequence data were analysis using ABsequence3 and MEGA ver 6. Alignment of $C O I$ gene was done using BLAST integrated in GenBank. Collected shark fins were obtained from four different individuals. BLAST results showed that all shark fins identified as Triaenodon obesus. Maximum and total scores, E-value, percentage of query cover, and the percentage of identity, between $604-1245,0.0,70-99 \%$ and 92-99\%, respectively.

Keywords : DNA Barcode, Shark fin, COI gene, North Sulawesi

Populasi ikan hiu global menunjukkan penurunan yang signifikan karena; penangkapan yang masif dan tak terkontrol, karakter biologi reproduksi yang lambat serta fekunditas yang rendah. Indonesia merupakan salah satu negara kontributor terbesar dalam perdagangan sirip ikan hiu dunia. Tingginya aktifitas perdagangan sirip tersebut berpengaruh terhadap populasi ikan hiu dan berdampak pada turunnya kualitas keseimbangan ekosistem laut. Tujuan penelitian ini untuk mengidentifikasi ikan hiu dari potongan sirip yang didapat dari pengumpul di Tumbak, Minahasa Tenggara menggunakan DNA barcode. Ekstraksi DNA genom sirip hiu kering dilakukan dengan menggunakan prosedur DNeasy Blood \& Tissue kit, amplifikasi gen Cytochrome Oxidase Subunit 1 (COI) dilakukan dengan menggunakan primer Fish BCL5 (TCAACYAATCAYAAAGATATYGGCAC) dan HCO2198 (TAAACTTCAGGGTGACCAAAAAA TCA). Pengolahan data sekuens dilakukan dengan menggunakan program ABsequence3 dan MEGA ver 6. Pencocokan karakter nukleotida gen COI dilakukan dengan menggunakan program nBLAST yang terintegrasi pada laman GenBank. Sampel sirip yang berhasil dikoleksi berasal dari 4 individu yang berbeda. Hasil nBLAST menunjukkan bahwa keempat sampel sirip hiu tersebut teridentifikasi sebagai spesies Triaenodon obesus. Nilai keakuratan pensejajaran sekuens, nilai dugaan, prosentase panjang nukleotida yang selaras, dan prosentase tingkat kemiripan, masing-masing pada nilai antara 604-1245, 0.0, 70-99\% dan 92-99\%.

Kata kunci : DNA Barcode, Sirip ikan hiu, Gen COI, Sulawesi Utara

\section{PENDAHULUAN}

Teknik biologi molekuler dapat membantu keberlanjutan dunia hayati yang semakin terancam karena minimnya informasi genetik membuat spesies dikhawatirkan punah sebelum dikenali. Efektifitas sistem dan teknik biologi molekuler sangat penting untuk konservasi sumberdaya genetik suatu spesies dengan tingkat akurasi yang 
tinggi dalam upaya kelestarian mahkluk hidup. Metode identifikasi spesies makhluk hidup telah berkembang mulai dari identifikasi morfologi sampai pada identifikasi molekuler berdasarkan pada potongan DNA pendek yang disebut DNA Barcode (Hebert et al. 2003). DNA Barcode merupakan suatu teknik identifikasi spesies, aplikasinya mirip dengan teknologi pemindaian Barcode pada produk komersial. Gen pengkode protein yang digunakan untuk identifikasi spesies adalah gen Cytochrome $c$ oxidase I (COI). COI merupakan sekuen gen pendek yang dipilih diantara banyaknya gen yang digunakan sebagai gen standar identifikasi khusus untuk spesies hewan berbasis DNA Barcode (Zein, 2007).

Populasi ikan hiu secara global menunjukkan penurunan yang signifikan sehubungan dengan adanya penangkapan ikan hiu yang masif dan tak terkontrol. Penurunan populasi ini makin diperparah dengan karakter biologi reproduksi ikan hiu yang lambat dalam mencapai masa kawin serta rendahnya fekunditas dari organisme ini (Carrier et al. 2010). Saat ini, hampir $90 \%$ spesies ikan hiu telah dikategorikan sebagai spesies yang terancam punah, langka dan dilindungi. Menurut data konsevasi yang dipublikasikan oleh International Union for Concervation of Nature (IUCN) red list,Indonesia dihuni oleh sekitar 118 spesies dari 200 spesies ikan hiu yang ada, dan dilaporkan sebagai negara kontributor terbesar sirip ikan hiu dunia dengan produksi antara 60.000 - 100.000 ton/tahun (Sadidi, 2013). Tingginya aktifitas perdagangan sirip ikan hiu tentu berpengaruh besar terhadap populasi ikan hiu lokal hingga global, yang berdampak pada turunnya kualitas keseimbangan ekosistem laut (Carrier et al. 2010). Oleh karena itu identifikasi yang akurat untuk spesies ikan hiu hasil tangkapan atau yang diperdagangkan sangat perlu dilakukan, sebagai acuan dasar dalam penentuan status konservasi. Tujuan penelitian ini adalah untuk mengidentifikasi ikan hiu dari potongan sirip yang didapat dari pengumpul di Tumbak, Minahasa Tenggara melalui teknik DNA Barcode.

\section{METODE PENELITIAN}

Sirip hiu didapat dari desa Tumbak, Minahasa Tenggara, Sulawesi Utara. Jumlah potongan sirip hiu yang berhasil diperoleh sebanyak empat potong sirip yang berasal dari individu berbeda. Analisis tampakan fisik dan molekuler sirip ikan hiu dilakukan di Laboratorium Biologi Molekuler dan Farmasitika Laut, Fakultas Perikanan dan Ilmu Kelautan, Universitas Sam Ratulangi, Manado.

Ekstraksi DNA genom sirip ikan hiu dilakukan dengan mengikuti prosedur DNeasy Blood \& Tissue kit (www.qiagen.com). Sampel dilisis menggunakan buffer ATL dan DNA total dari sampel dipisahkan dari protein dan debris menggunakan proteinase $K$ dan buffer AL. DNA total dikoleksi menggunakan DNeasy mini spin kolom dilanjutkan dengan proses pemurnian DNA menggunakan buffer AW1 dan buffer AW2. DNA total yang terkoleksi dalam spin filter dipindahkan ke elution tube yang telah disiapkan dengan menggunakan buffer $A E$.

Amplifikasi gen COI menggunakan primer forward (Fish BCL5 TCAACYAATCAYAAAGATATYGGCAC) dan primer referse (HCO2198 TAAACTTCAGGGTGACCAAAAAATCA). DNA diamplifikasi menggunakan $5 \times$ HOT Firepol Master Mix. Total volume yang digunakan untuk amplifikasi adalah 25 $\mu \mathrm{L}$, yang terdiri atas $1 \mu \mathrm{L}$ DNA sampel dan $1 \mu \mathrm{L}$ volume dari masing-masing primer. Amplifikasi DNA menggunakan mesin PCR TPersonal (Biometra) dengan pengaturan suhu sebagai berikut: predenaturasi pada suhu $95^{\circ} \mathrm{C}$ selama 2 menit, denaturasi pada suhu $95^{\circ} \mathrm{C}$ selama 40 detik dilakukan sebanyak 37 siklus, annealing pada suhu $50^{\circ} \mathrm{C}$ selama 40 detik 37 siklus, elongasi pada suhu $72^{\circ} \mathrm{C}$ selama 40 detik sebanyak 37 siklus dan 1 siklus perpanjangan akhir pada suhu $72^{\circ} \mathrm{C}$ selama 1 menit. 
Keberhasilan amplifikasi gen COI diperiksa menggunakan gel berkonsentrasi $1 \%$ yang ditambahkan dengan maestrosafe prestained sebanyak $2 \mu \mathrm{L}$. Produk amplifikasi DNA sebanyak $4 \mu \mathrm{L}$ dan $1 \mu \mathrm{L} 10 x$ loading buffer dan dimasukakkan dalam masingmasing sumur yang telah disiapkan dalam gel. Pada salah satu sumur dalam gel diisi dengan $2 \mu \mathrm{L}$ ladder DNA marker (1 kb). Elektroforesis menggunakan $1 x$ TBE buffer dan dialiri dengan tegangan listrik sebesar 80 volts dengan waktu kurang lebih 20 menit. Hasil pemeriksaan gel elektroforesis diamati lewat sinar UVtransluminator yang diikuti dengan dokumentasi. Produk amplifikasi yang menunjukan adanya pita pada panjang basa sekitar 600-700 bp selanjutnya dikirim ke jasa pelayanan sekuensing FIRST BASE, Malaysia.

Hasil sekuensing dari spesimen sirip hiu didapat dalam bentuk kromatogram, hasil sekuens dua arah menggunakan primer forward dan reverse. Kualitas hasil sekuens dianalisis menggunakan program ABsequence3, diantaranya kualitas hasil sekuens ditentukan pada $\mathrm{QV}^{+20}$ (quality value lebih besar dari 20) dan CRL (continuous read length). Penyusunan DNA consensus menggunakan perangkat lunak MEGA ver.6, yang meliputi; proses trimming, reverse compliment dan alignment. Proses alignment dilakukan dengan bantuan software MUSCLE yang terintegrasi dalam program MEGA 6 (Tamura et al. 2013). Sekuens yang telah melalui proses alignment, selanjutnya dicocokan ke database nukleotida yang terdapat pada situs database nukleotida secara online, yaitu situs GenBank National Center for Biotechnology Information (http://www.ncbi.nlm.nih. gov/). Sekuens DNA consensus dicocokkan ke database genbank dengan menggunakan fasilitas nucleotida blast yang terintegrasi di laman GenBank. Hasil BLAST umumnya menghasilkan lebih dari satu sekuens yang bersesuaian. Informasi dari hasil BLAST tersebut berupa Score, Query Coverage, E-value dan Identity. Nilai score menunjukkan keakuratan nilai penjajaran sekuens berupa nukleotida yang tidak diketahui dengan sekuens nukleotida yang terdapat di dalam GenBank. Semakin tinggi nilai score yang diperoleh maka semakin tinggi tingkat homologi kedua sekuens. Query coverage adalah persentasi dari panjang nukleotida yang selaras dengan karakter nukleotida dalam database. Identity adalah nilai tertinggi dari persentasi identitas atau kecocokan antara sekuen query dengan sekuen database yang tersejajarkan. Nilai Expect value merupakan nilai dugaan yang memberikan ukuran statistik yang signifikan terhadap kedua sekuen. Nilai E-value yang semakin tinggi menunjukkan tingkat homologi antar sekuens akan semakin rendah, sedangkan nilai $E$-value yang semakin rendah menunjukkan tingkat homologi antar sekuens akan semakin tinggi. Nilai E-value bernilai 0 (nol) menunjukkan bahwa kedua sekuens tersebut identik (Claverie dan Notredame, 2003).

\section{HASIL DAN PEMBAHASAN}

Total sirip hiu yang diperoleh dari pengumpul yang ada di Tumbak Minahasa Tenggara, berjumlah empat sirip dari individu berbeda. Bentuk dan tampakan keempat sirip hiu tersebut ditampilkan pada Gambar 1.

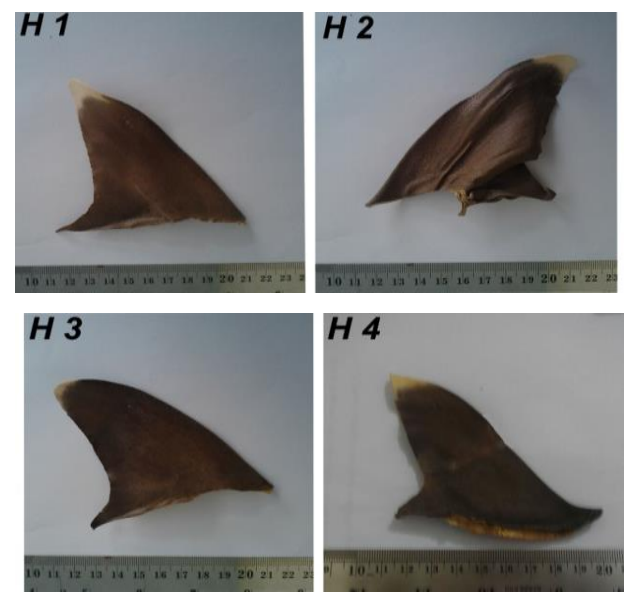

Gambar 1. Bentuk dan tampakan sirip ikan hiu yang didapat di Tumbak, Minahasa Tenggara. 
$\begin{array}{llll}M(1 k b) & H 1 & H & H\end{array}$

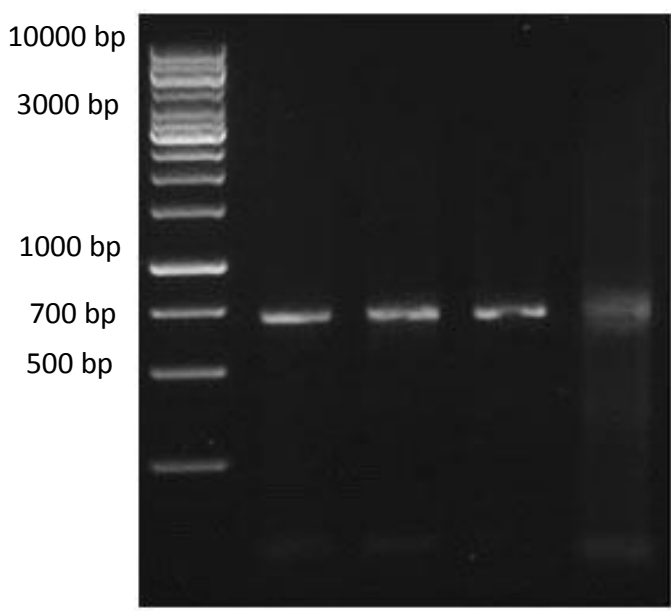

Gambar 2. Hasil eletroforesis produk PCR gen COI dari spesimen sirip ikan hiu

Hasil ekstraksi DNA genom sirip ikan hiu telah digunakan sebagai DNA template dalam proses amplifikasi gen COI. Elektroforesis produk PCR (Gambar 2) menunjukkan adanya pita DNA pada masing-masing lintasan sampel DNA yang teramati pada posisi panjang amplikon sekitar 600-700 bp dengan menggunakan ukuran $1 \mathrm{~kb}$ DNA ladder sebagai pembanding. Posisi panjang amplikon tersebut sesuai dengan posisi panjang basa gen $\mathrm{COI}$ yang banyak digunakan sebagai penanda universal dalam identifikasi spesies hewan menurut Habert et al (2003).

Analisa kualitas hasil sekuensing menunjukan bahwa nilai $\mathrm{QV}^{+20}$ dan $\mathrm{CRL}$ sirip hiu kode $\mathrm{H} 1, \mathrm{H} 3$ (for) dan $\mathrm{H} 4$ berada di atas 500 nukleotida, sedangkan sirip hiu kode $\mathrm{H} 2$ dan $\mathrm{H} 3$ (rev) menunjukan nilai yang lebih rendah, yaitu antara 146294 nukleotida (Tabel 1).

Hasil pengurutan DNA gen COI selanjutnya disunting menggunakan perangkat lunak MEGAv6. DNA consensus masing-masing specimen telah disusun dengan melakukan pemotongan basa berkualitas kurang baik. Hasil penyusunan DNA consensus dari masing-masing spesimen telah diubah ke dalam format FASTA dan mendapatkan sejumlah urutan nukleotida, selanjutnya urutan nukleotida masingmasing spesimen dicocokkan dengan laporan urutan DNA yang terdokumentasi di GanBank (NCBI).

Hasil BLAST di situs GenBank menggunakan DNA consensus sirip hiu kode $\mathrm{H} 1, \mathrm{H} 2, \mathrm{H} 3$ dan $\mathrm{H} 4$ mendapatkan sejumlah laporan (100 hits) yang memiliki skor kemiripan yang tinggi, yaitu pada kisaran lebih besar 200 nukleotida. Cuplikan laporan teratas hasil BLAST DNA consensus gen COI sirip kode $\mathrm{H} 1$, $\mathrm{H} 2$, H3, dan H4 ditampilkan pada Tabel 2. Hasil BLAST sekuens sirip hiu H2 yang menunjukan skor kekakuratan pensejajaran sekuens 604, prosentasi panjang nukleotida selaras $70 \%$ dan prosentase tingkat kemiripan sekuens 92\% dan merujuk pada spesies Triaenodon obesus. Hasil BLAST sirip hiu kode $\mathrm{H} 1, \mathrm{H} 3$ dan $\mathrm{H} 4$ menunjukan skor kekakuratan pensejajaran sekuens

Tabel 1. Kualitas hasil sekuens sirip ikan hiu yang dianalisis menggunakan program ABsequence. CRL (continuous read length) dan QV (quality value +20$)$.

\begin{tabular}{lllll}
\hline No & $\begin{array}{l}\text { Kode } \\
\text { Sampel }\end{array}$ & Primer & CRL & QV20+ \\
\hline \multirow{2}{*}{1} & \multirow{2}{*}{ H1 } & For & 649 & 651 \\
& & Rev. & 650 & 656 \\
\hline \multirow{2}{*}{2} & \multirow{2}{*}{ H2 } & For. & 146 & 294 \\
\multirow{2}{*}{3} & \multirow{2}{*}{ H 3 } & Rev. & 157 & 266 \\
\hline \multirow{2}{*}{4} & \multirow{2}{*}{ H 4 } & For. & 646 & 648 \\
& & Rev. & 160 & 155 \\
\hline
\end{tabular}


Tabel 2. Cuplikan hasil penelusuran teratas menggunakan sekuens gen COI sirip hiu kode H1, H2, H3 dan H4 di situs GenBank (tanggal akses 31 Januari 2017).

\begin{tabular}{|c|c|c|c|c|c|c|}
\hline Description & $\begin{array}{l}\text { Max } \\
\text { Score }\end{array}$ & $\begin{array}{l}\text { Total } \\
\text { Score }\end{array}$ & $\begin{array}{l}\text { Query } \\
\text { cover }\end{array}$ & $\begin{array}{l}\mathrm{E}- \\
\text { value }\end{array}$ & $\begin{array}{l}\text { Identi } \\
\text { ty }\end{array}$ & $\begin{array}{l}\text { Acc. } \\
\text { numb }\end{array}$ \\
\hline \multicolumn{7}{|l|}{ Sirip hiu kode $\mathrm{H} 1$} \\
\hline $\begin{array}{l}\text { Triaenodon obesus mitochondrion, complete } \\
\text { genome }\end{array}$ & 1245 & 1245 & $99 \%$ & 0.0 & $99 \%$ & $\begin{array}{l}\text { KJ7483 } \\
76.1\end{array}$ \\
\hline $\begin{array}{l}\text { Triaenodon obesus cytochrome oxidase subunit } 1 \\
\text { (COI) gene, partial cds; mitochondrial }\end{array}$ & 1223 & 1223 & $95 \%$ & 0.0 & $99 \%$ & $\begin{array}{l}\text { KM3969 } \\
47.1\end{array}$ \\
\hline $\begin{array}{l}\text { Triaenodon obesus voucher IBRC.01.70.02 } \\
\text { cytochrome oxidase subunit } 1 \text { (COI) gene, partial } \\
\text { cds; mitochondrial }\end{array}$ & 1208 & 1208 & $93 \%$ & 0.0 & $100 \%$ & $\begin{array}{l}\text { KF5903 } \\
61.1\end{array}$ \\
\hline $\begin{array}{l}\text { Triaenodon obesus voucher NBFGR:CHN:NC1 } \\
\text { cytochrome c oxidase subunit I (COI) gene, partial } \\
\text { cds; mitochondrial }\end{array}$ & 1205 & 1205 & $93 \%$ & 0.0 & $99 \%$ & $\begin{array}{l}\text { KF8997 } \\
64.1\end{array}$ \\
\hline $\begin{array}{l}\text { Triaenodon obesus voucher SOSSRC:Triaenodon } \\
\text { obesus OC-2 cytochrome oxidase subunit I (COI) } \\
\text { gene, partial cds; mitochondrial }\end{array}$ & 1205 & 1205 & $93 \%$ & 0.0 & $100 \%$ & $\begin{array}{l}\text { FJ51928 } \\
8.1\end{array}$ \\
\hline \multicolumn{7}{|l|}{ Sirip hiu kode H2 } \\
\hline $\begin{array}{l}\text { Triaenodon obesus haplotype 40_57 cytochrome } \\
\text { oxidase subunit I (COI) gene, partial cds; } \\
\text { mitochondrial }\end{array}$ & 604 & 604 & $70 \%$ & $\begin{array}{l}6 e- \\
169\end{array}$ & $92 \%$ & $\begin{array}{l}\text { KT2752 } \\
39.1\end{array}$ \\
\hline $\begin{array}{l}\text { Triaenodon obesus haplotype 39_56 cytochrome } \\
\text { oxidase subunit I (COI) gene, partial cds; } \\
\text { mitochondrial }\end{array}$ & 604 & 604 & $70 \%$ & $\begin{array}{l}6 e- \\
169\end{array}$ & $92 \%$ & $\begin{array}{l}\text { KT2752 } \\
38.1\end{array}$ \\
\hline $\begin{array}{l}\text { Triaenodon obesus haplotype } 38 \text { 54 cytochrome } \\
\text { oxidase subunit I (COI) gene, partial cds; } \\
\text { mitochondrial }\end{array}$ & 604 & 604 & $70 \%$ & $\begin{array}{l}6 e- \\
169\end{array}$ & $92 \%$ & $\begin{array}{l}\text { KT2752 } \\
37.1\end{array}$ \\
\hline $\begin{array}{l}\text { Triaenodon obesus haplotype } 37 \text { _53 cytochrome } \\
\text { oxidase subunit I (COI) gene, partial cds; } \\
\text { mitochondrial }\end{array}$ & 604 & 604 & $70 \%$ & $\begin{array}{l}6 e- \\
169\end{array}$ & $92 \%$ & $\begin{array}{l}\text { KT2752 } \\
36.1\end{array}$ \\
\hline $\begin{array}{l}\text { Triaenodon obesus haplotype } 36 \text { 52 cytochrome } \\
\text { oxidase subunit I (COI) gene, partial cds; } \\
\text { mitochondrial }\end{array}$ & 604 & 604 & $70 \%$ & $\begin{array}{l}6 e- \\
169\end{array}$ & $92 \%$ & $\begin{array}{l}\mathrm{KT} 2752 \\
35.1\end{array}$ \\
\hline \multicolumn{7}{|l|}{ Sirip hiu kode H3 } \\
\hline $\begin{array}{l}\text { Triaenodon obesus mitochondrion, complete } \\
\text { genome }\end{array}$ & 1177 & 1177 & $100 \%$ & 0.0 & $99 \%$ & $\begin{array}{l}\text { KJ7483 } \\
76.1\end{array}$ \\
\hline $\begin{array}{l}\text { Triaenodon obesus voucher CYO- } 19 \text { cytochrome } \\
\text { oxidase subunit } 1 \text { (COI) gene, partial cds; } \\
\text { mitochondrial }\end{array}$ & 1162 & 1162 & $99 \%$ & 0.0 & $99 \%$ & $\begin{array}{l}\text { KC9705 } \\
12.1\end{array}$ \\
\hline $\begin{array}{l}\text { Triaenodon obesus cytochrome oxidase subunit } 1 \\
\text { (COI) gene, partial cds; mitochondrial }\end{array}$ & 1151 & 1151 & $96 \%$ & 0.0 & $99 \%$ & $\begin{array}{l}\text { KM3969 } \\
47.1\end{array}$ \\
\hline $\begin{array}{l}\text { Triaenodon obesus voucher IBRC.01.70.02 } \\
\text { cytochrome oxidase subunit } 1 \text { (COI) gene, partial } \\
\text { cds; mitochondrial }\end{array}$ & 1147 & 1147 & $96 \%$ & 0.0 & $100 \%$ & $\begin{array}{l}\text { KF5903 } \\
61.1\end{array}$ \\
\hline $\begin{array}{l}\text { Triaenodon obesus voucher NBFGR:CHN:NC1 } \\
\text { cytochrome c oxidase subunit I (COI) gene, partial } \\
\text { cds; mitochondrial }\end{array}$ & 1142 & 1142 & $96 \%$ & 0.0 & $99 \%$ & $\begin{array}{l}\text { KF8997 } \\
64.1\end{array}$ \\
\hline \multicolumn{7}{|l|}{ Sirip hiu kode H4 } \\
\hline $\begin{array}{l}\text { Triaenodon obesus mitochondrion, complete } \\
\text { genome }\end{array}$ & 1155 & 1155 & $99 \%$ & 0.0 & $99 \%$ & $\begin{array}{l}\text { KJ7483 } \\
76.1\end{array}$ \\
\hline $\begin{array}{l}\text { Triaenodon obesus voucher CYO-19 cytochrome } \\
\text { oxidase subunit } 1 \text { (COI) gene, partial cds; } \\
\text { mitochondrial }\end{array}$ & 1146 & 1146 & $100 \%$ & 0.0 & $99 \%$ & $\begin{array}{l}\text { KC9705 } \\
12.1\end{array}$ \\
\hline $\begin{array}{l}\text { Triaenodon obesus cytochrome oxidase subunit } 1 \\
\text { (COI) gene, partial cds; mitochondrial }\end{array}$ & 1144 & 1144 & $98 \%$ & 0.0 & $99 \%$ & $\begin{array}{l}\text { KM3969 } \\
47.1\end{array}$ \\
\hline $\begin{array}{l}\text { Triaenodon obesus voucher IBRC. } 01.70 .02 \\
\text { cytochrome oxidase subunit } 1 \text { (COI) gene, partial } \\
\text { cds; mitochondrial }\end{array}$ & 1140 & 1140 & $97 \%$ & 0.0 & $100 \%$ & $\begin{array}{l}\text { KF5903 } \\
61.1\end{array}$ \\
\hline $\begin{array}{l}\text { Triaenodon obesus voucher NBFGR:CHN:NC1 } \\
\text { cytochrome c oxidase subunit I (COI) gene, partial } \\
\text { cds; mitochondrial }\end{array}$ & 1134 & 1134 & $97 \%$ & 0.0 & $99 \%$ & $\begin{array}{l}\text { KF8997 } \\
64.1\end{array}$ \\
\hline
\end{tabular}

$(>1000)$, prosentasi panjang nukleotida selaras (93-100\%), prosentase tingkat kemiripan sekuens $(99-100 \%)$ yang tinggi, dan nilai dugaan $(0.0)$ yang rendah yang mengindikasikan tingkat kemiripan yang tinggi dengan spesies Triaenodon obesus. Drancourt et al. (2000), dalam Asnani et al. (2015) menambahkan 


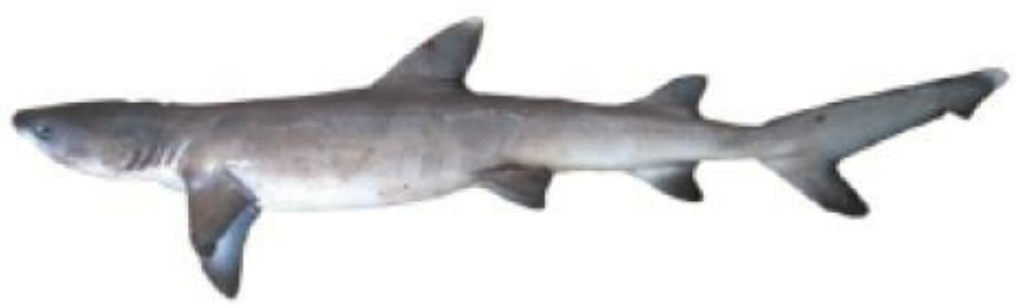

Gambar 3. Struktur tubuh Triaenodon obesus (White et al. 2006).

bahwa prosentase tingkat kemiripan sekuens yang berada pada nilai $\geq 99 \%$ menunjukkan bahwa spesies yang dibandingkan merupakan spesies yang sama.

T. obesus merupakan jenis hiu yang berkeliaran dekat terumbu karang, dan dikenal dengan nama Whitetip Reef Shark. Menurut White et al. (2006), spesies ini mempunyai ciri umum yaitu, ujung sirip punggung dan ujung sirip ekor berwarna putih, Panjang tubuh dapat mencapai $200 \mathrm{~cm}$, pada ikan jantan dan betina dewasa berukuran 105-120 cm. Spesies ini biasa dijumpai diseluruh perairan Indo-Pasifik, hidup di daerah pantai atau dasar perairan yang bercelah atau berlubang dan didaerah terumbu karang yang berair jernih, dengan kedalaman antara 1-40 m. Menurut data konservasi internasional yaitu data IUCN (international Union for Concervation Nature) Redlist spesies ini berada di kategori near threatened atau hampir terancam (Gambar 3).

\section{KESIMPULAN}

Hasil koleksi sirip ikan hiu di Tumbak, Minahasa Tenggara, Sulawesi Utara mendapatkan 4 spesimen sirip yang berasal dari individu yang berbeda. Identifikasi molekuler masing-masing sirip menggunakan teknik DNA barcode menunjukan bahwa keempat spesies tersebut merujuk pada spesies Triaenodon obesus.

\section{DAFTAR PUSTAKA}

Asnani, A., Ryandini, D., Suandri. 2015. Karakterisasi dan identifikasi spesies aktinomisetes k-3e. DOI: 10.13140/RG.2.1.4469.1922.

Carrier, J.C., Musick, J.A.,. Heithaus. M.R 2010. Shark and their relatives II: Biodiversity, adaptive physiology and conservation. CRC Press Boca Raton London New york. .

Claveire, J.M., Notredame,C. 2003. Bioinformatics for Dummies. Wiley Publishing, Indianapolis.

Hebert, P.D.N., Cywinska, A., Ball, S. L. 2003. Biological identifications through DNA barcodes.

Proceedings of the Royal Society of London. Series B: Biological Sciences, 270(1512):313-321.

IUCN-SSC. 2001. IUCN Red list categories and criteria IUCN-The World Conservation Union. Gland. Swizerland and Cambridge. http://www.iucnredlist.org/.

NCBI. 1988. National Center for Biotechnology Information, U.S. National Library of Medicine.[Computer software]. www.ncbi.nlm.nih.gov.

Qiagen. 2006. DNeasy Blood and Tissue Handbook: DNeasy Blood and Tissue Kit, DNeasy 96 Blood \& Tissue Kit. www.qiagen.com. 
Sadidi, D. 2013. Upaya Meningkatkan Konservasi Ikan Hiu. http://didisadili.blogspot.co.id/2013 /12/upaya-meningkatkankonservasi-ikan-hiu.html. diakses januari 2016.

Tamura K., Stecher, G., Peterson, D., Filipski, A.. Kumar, S. 2013. MEGA 6: Molecular Evolutionary Genetics Analysis version 6.0. [Computer software]. Molecular Biology and Evolution. 30:27252729.

White, W.T., Last, P.R., Stevens, J.D. Yarsley, G.K., Fahmi, Darmadi. 2006. Economycally important shark \& rays Indonesia. Australian Centre for International Agricultural Research, Canberra, Australia 2601. 327.

Zein, M.S.A. 2007. DNA barcode keragaman genetic, dan konservasi fauna Indonesia. Laboratorium genetika bidang zoology pusat peneliti biologi LIPI. 70 hal. 